\title{
Notes on the typification of some species of Aloe (Asphodelaceae/Aloaceae)
}

\author{
H.F. GLEN ${ }^{*}$ and G.F. SMITH
}

ABSTRACT

Lecto- or neotypes are designated for Aloe thompssmiae Groencw.. A. micracantha Haw.. A. schmidriana Regel (a synonym of A. cooperi Baker), A. longistyla Baker. A. aristata Haw., A. longiaristaks Schult. \& Schult. f., (a strnonym of the preceding name), A. humilis (L.) Mill. var. incurva Haw., A. glauca Mill., A. muricata Schult. (a synonym of the preceding name). A. sapemaria (Aiton) Haw. var. latifolia $\mathrm{Haw}$. (a new synonym of A. macculata All.) and A. pluridens Haw. The confusing citation of the type of A. therncroffii Pole Evans is clarified.

\section{UITTREKSEI}

Lekto- of neotipes word dangewys vir Aloe thompsomicse Groenew., A. micracantha Haw.. A. schmidtiana Regel ("n sinoniem van A. cooperi Baker). A. longistyla Baker. A. aristala Haw.. A. longiaristata Schult. \& Schult. f. ('n sinoniem van die voorafgaande naam). A. humilis (L.) Mill. var. incuna Haw., A. glauca Mill.. A. muricala Schult. ("n sinoniem van die vorafgaande natam). A. sapomaria (Aiton) Haw. var. latifolia Haw. ('n nuwe sinoniem van A. maculata All.) en A. pluridens Haw. Die verwarrende sitering van die tipe-eksemplatar van A. thorncrofrii Pole Evans word opgeklaar.

\section{INTROI)U(TION}

In the course of studies directed towards both a revision of the southern African species of Aloe and the data capture for PRECIS-FLORA. it was found that the typification of several well known names was ambiguous. Details necessary to remove the ambiguity in three cases were recently published in some detail by Smith $(1990 \mathrm{a}$, b) and Glen \& Hardy (1991), but these are only three of the more involved cases. In a significant number of instances. all that is required is the choice of a lectotype or neotypewhich hardly merits a separate paper, or even a separate shon note, for each name. The purpose of this paper, then. is to gather up all these problems into a single worthwhile publication.

Typification of extant yet untypified names is not obligatory (Art. 9.9 of the International Code of Botanical Nomenclature, but see Art. 1(0.2). In a taxonomically difficult genus such as Aloe, however, typitication is often necessary to establish the application of the plethora of available names. Furthermore, it tixes the concepts of the present authors regarding selected names in Aloe that should be reduced to synonymy.

The names in question are considered in a taxonomic order approximating that used by Berger $(1908)$ and Reynolds (1950). They are dealt with in groups roughly following those employed by these authors. In all cases. lectotypes and neotypes have been chosen bearing in mind two criteria. In order of impontance. these are: I. preservation of current usage, as far as possible establishing the intent of the original author. and 2. accessibility of material.

\footnotetext{
National Botanical Institute. Private Batg X/01. Pretoria (xom) MS. received $1(x) 4.01324$
}

\section{NOTES ON TYPIFICATION}

Aloe thomponniac Groenew: in Tydskrif vir Wetenskap en Kuns 14: 64 (1936) sphalm. thompsomi. Loctotype: Transvalal. Haenentsburg. Thompson s.n. in PRE 274 (PRE, lecto.!. here designated).

Although not cited by Groenewald (1936), who did not designate a type. the specimen designated here (Figure 1) is the only one in PRE that was collected by the person commemorated in the name. Dr (Mrs) Sheila Clifford Thompson of Haenertsburg. Pietersburg District (Reynolds 1946: Prinsloo 1972) and is therefore relevant type material. In this context it is also noteworthy that Dr F. $Z$. van der Merwe. an avid collector of aloes in the mid190()$^{\circ} \mathrm{s}$, passed most of his newly described species of Aloe on to Mr B. H. Groenewald who dexeribed them and deposited the specimens in PRE (Gunn \& Codd 1981). In general it is therefore not worth searching other herbaria for material suitable as lectotypes of the names of species described by Groenewald.

Aloe micracantha How. (micnecuntha auct.) in Supplementum plantarum succulentarum: 105 (1819). Neotype: Burchell 4482 (K!. here designated).

Haworth (1819) cites no type for this species, but states that he saw a small plant collected in the wild and planted in the Royal Botanic Gardens. Kew. Sims (1821) states 'For this very rare species, which is supposed not to exist in any of our other collections except in that of Kew. where it was introduced about two years since from the Cape of Good Hope. we are indebted to Thomas Kitchin. Esq.. of Norwich. in whose garden. rich in succulent plants, it flowered in July last. Therefore one is ultimately forced to rely on Sims's skill and good faith in having compared the Kew and Norwich plants (neither of which is accessible any more). This problem of speculative typification based on circumstantial evidence can fortunately be circumvented due to the existence in Kew of 

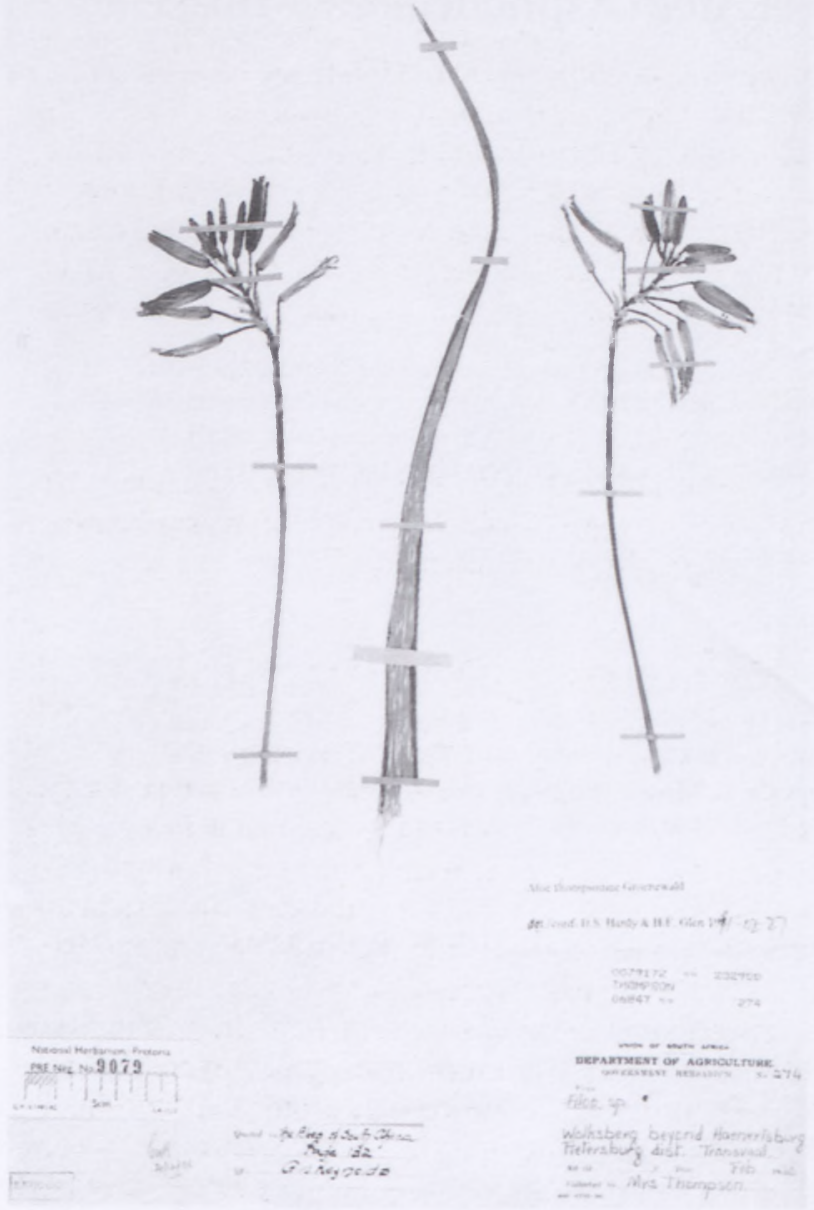

FIGURE 1.-Thompson s.n. (PRE 274), the lectotype specimen of Aloe thompsoniae.

two Burchell specimens of A. micracantha (Figure 2). They are both mounted on a single sheet, and are clearly identifiable with locality material nowadays referred to $A$. micracantha (Smith 1993). Selection of one of these specimens gives the name an accessible, readily identifiable type that stabilizes current usage. In addition, this specimen is the element that comes closest historically to being a live plant with which Haworth was familiar. Selection of either the Botanical Magazine plate of the species (Sims 1821), or an excellent colour plate kept at Kew of A. micracantha (Figure 3 ) as neotype for the name was considered, because, especially in the case of succulent plants, a drawing is often more diagnostic than a specimen and therefore more useful for fixing the application of a name (Smith 1990a). The Kew plate has often been attributed to Franz Bauer, but is by an unknown artist (G. Ll. Lucas pers. comm.). In the case of A. micracantha, the Burchell specimens are of such exceptional quality that one of them is the preferred choice (Figure 2). Of the two specimens available we chose Burchell 4482 (a whole plant) rather than Burchell 4564 (an inflorescence and two separate leaves), because the former gives a better idea of the appearance of the plant.

Aloe schmidtiana Regel in Gartenflora t. 970 (1879). Holotype: Gartenflora 97: t. 970.
It is unlikely that a herbarium specimen was prepared of the leaf and flower material referred to in the protologue. A very attractive illustration depicting $A$. cooperi Baker, however, accompanies the protologue. Since this plate is the one illustration used by the author (Art. 9.3 of the International Code of Botanical Nomenclature) it is here treated as the holotype.

Aloe longistyla Baker in Journal of the Linnean Society, Botany 18: 158 (1880). Lectotype: Cape, GraaffReinet, Bolus 689 (K, lecto.!; PRE, photo!, here designated).

Baker (1880) cites two specimens in the protologue of this species. The specimen Bolus 689 is chosen as lectotype rather than Drège 8640 because of its more detailed locality data (Figure 4).

Aloe aristata Haw. in Philosophical Magazine 66: 280 (1825). Neotype: Cape, near Steynsburg, Reynolds 1024 (PRE!, here designated).

Aloe longiaristata Schult. \& Schult. f. in Systema vegetabilium 7,1: 684 (1829). Neotype: Salm-Dyck, Monographia generum Aloës et Mesembryanthemi, Fasc. 2, fig. 21 [Sect. 15, fig. 7 (1837), here designated].

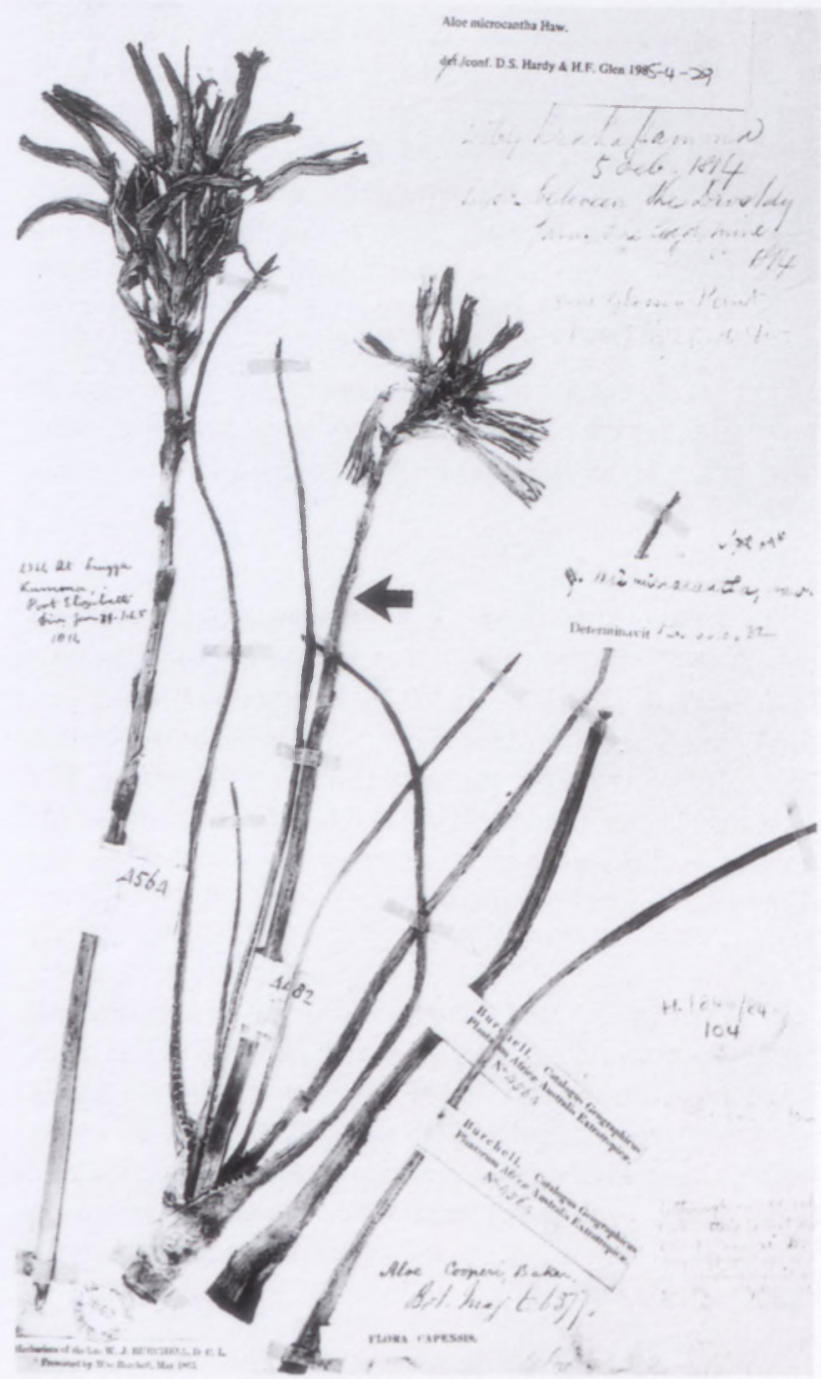

FIGURE 2.-Both Burchell specimens, 4482 and 4564, are mounted on the same sheet. The neotype of Aloe micracantha, Burchell 4482. is the complete one in the middle (arrowed). 


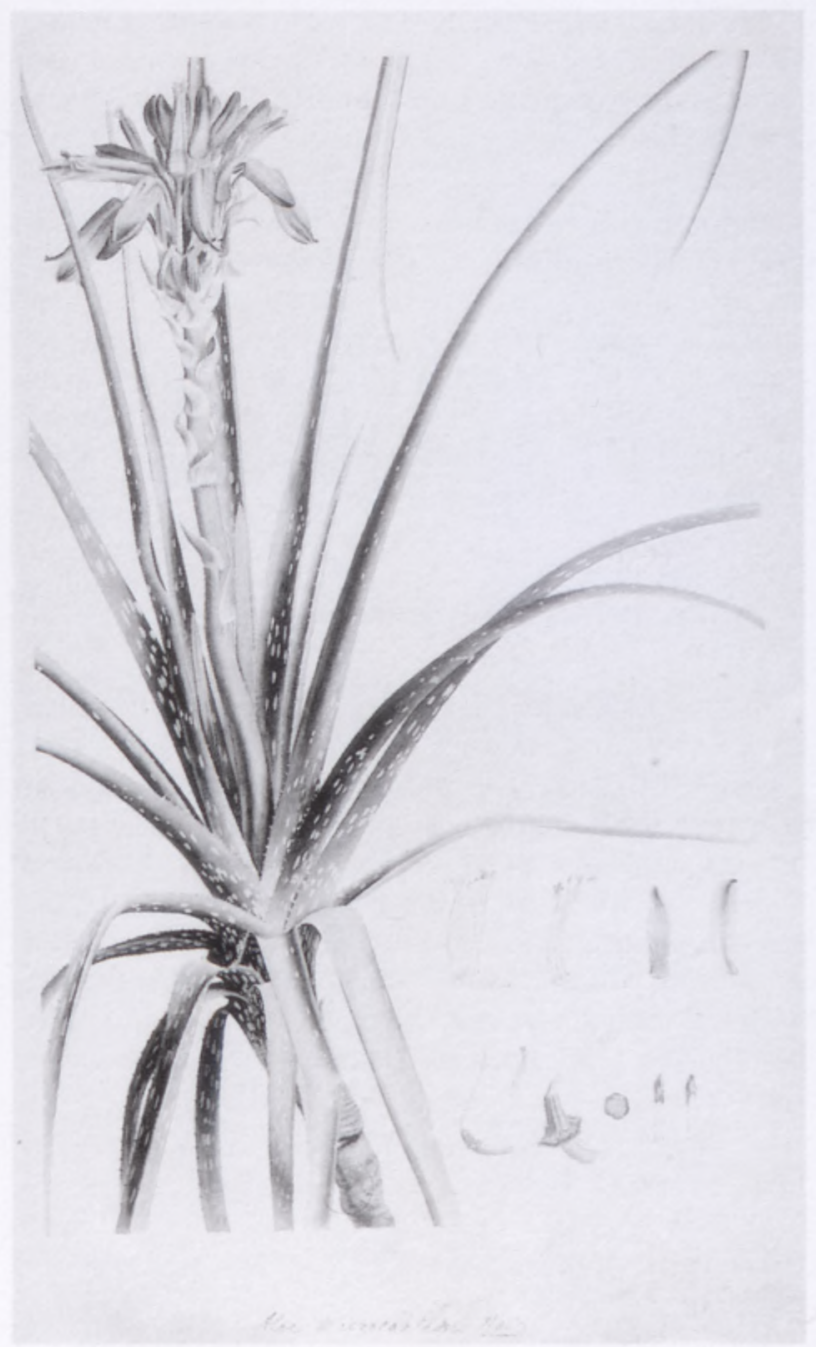

FIGURE 3.-Reduced photograph of an unpublished painting of Aloe micracantha by an unknown artist, probably not Franz Bauer as claimed by Reynolds (1950) (G. Ll. Lucas pers. comm.). Reproduced with permission of the Controller, Her Majesty's Stationery Office, and The Trustees, Royal Botanic Gardens, Kew.

As usual, Haworth gives no clue as to what material he had available when drawing up his description of $A$. aristata. In the absence of any contemporary or near-contemporary illustrations or specimens (no published reference was made to the name for 70 years after the protologue), a good modern specimen, Reynolds 1024, is chosen as neotype (Figure 5). One of its synonyms, $A$. longiaristata, is another name that is not in general use in the current taxonomy of the genus. However, it shows clearly how in the previous century names were based on etiolated plants grown ex situ thousands of miles away from their natural habitats (Salm-Dyck 1837). The plate chosen here as neotype of the name is the only obvious one that can serve the purpose. J. A. \& J. H. Schultes (1829) inexplicably included the validly published name, A. aristata, in the synonymy of $A$. longiaristata.

Aloe humilis (L.) Mill. var. incurva Haw. in Transactions of the Linnean Society 7: 15 (1804). Neotype (icono.): Curtis's Botanical Magazine 21: t. 828 (1805), here designated.
This is another case where a neotype is chosen for a name considered to be a synonym of another-the varieties of $A$. humilis intergrade so thoroughly as not to be worth upholding. Haworth (1804) has here, as is often the case, supplied no hint of the material he saw. Ker Gawler (1805) tells us that his plant came from a nursery in Kensington, which must surely have been known to Haworth, who at that time lived in Chelsea in the same part of the then southwestern outskirts of London. Again, the earliest available element is chosen, to stabilize current usage.

Aloe glauca Mill. in The Gardeners' Dictionary No. 16 (1768). Neotype: Cape, hills south of Wyke, Reynolds 1967 (PRE!, here designated).

Miller's protologue (1768) of this species gives a reference to a plate in Commelin (1703), which Wijnands (1983) shows clearly to represent a completely different species. Miller gives no other indication of a type for this name. As Wijnands (1983) points out, one is faced in this case with a choice of two options, both of which have undesirable features, namely: 1 , drawing the conclusion from the evidence so ably marshalled by Wijnands (1983) that Miller suffered a series of errors at the crucial point here, and stabilize current usage by conserving the name Aloe glauca Mill. with a completely new type, rejecting all references to his confused citation of Commelin illustrations; or 2, reject this well known name as a nomen confusum in favour of the next-oldest, securely identified name, $A$. rhodacantha DC. It seems to us that the first course is the less harmful, and so neotypes are proposed here for both A. glauca Mill. (Figure 6) and A. muricata

瓷

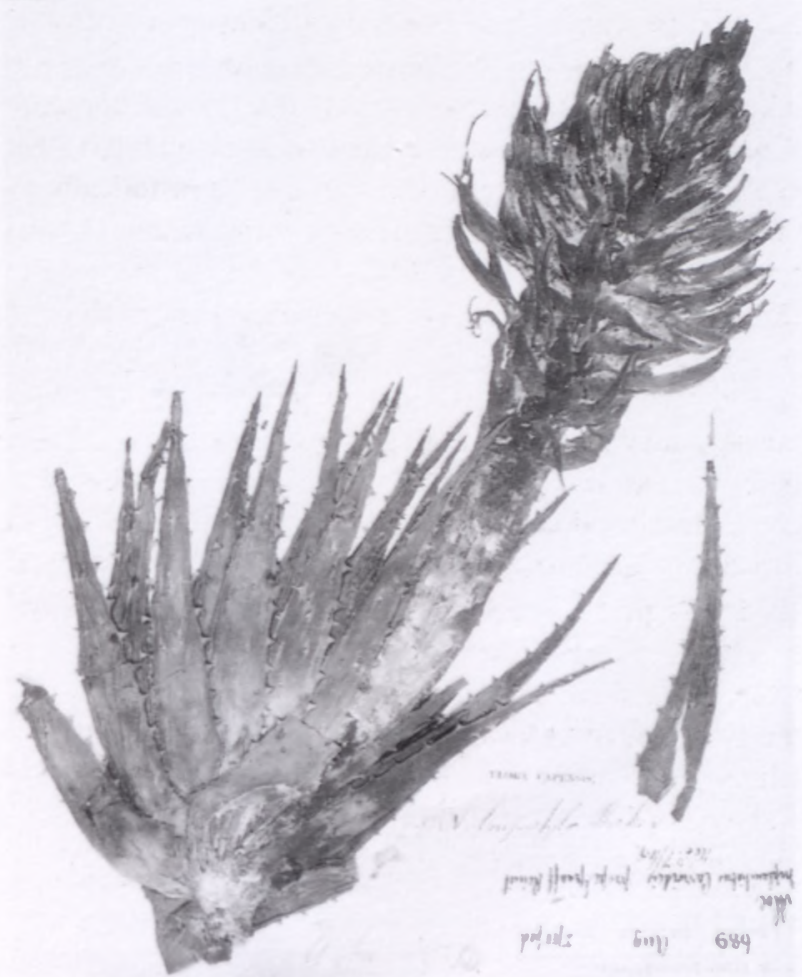

FIGURE 4,-Bolus 689, lectotype of Aloe longistyla. 


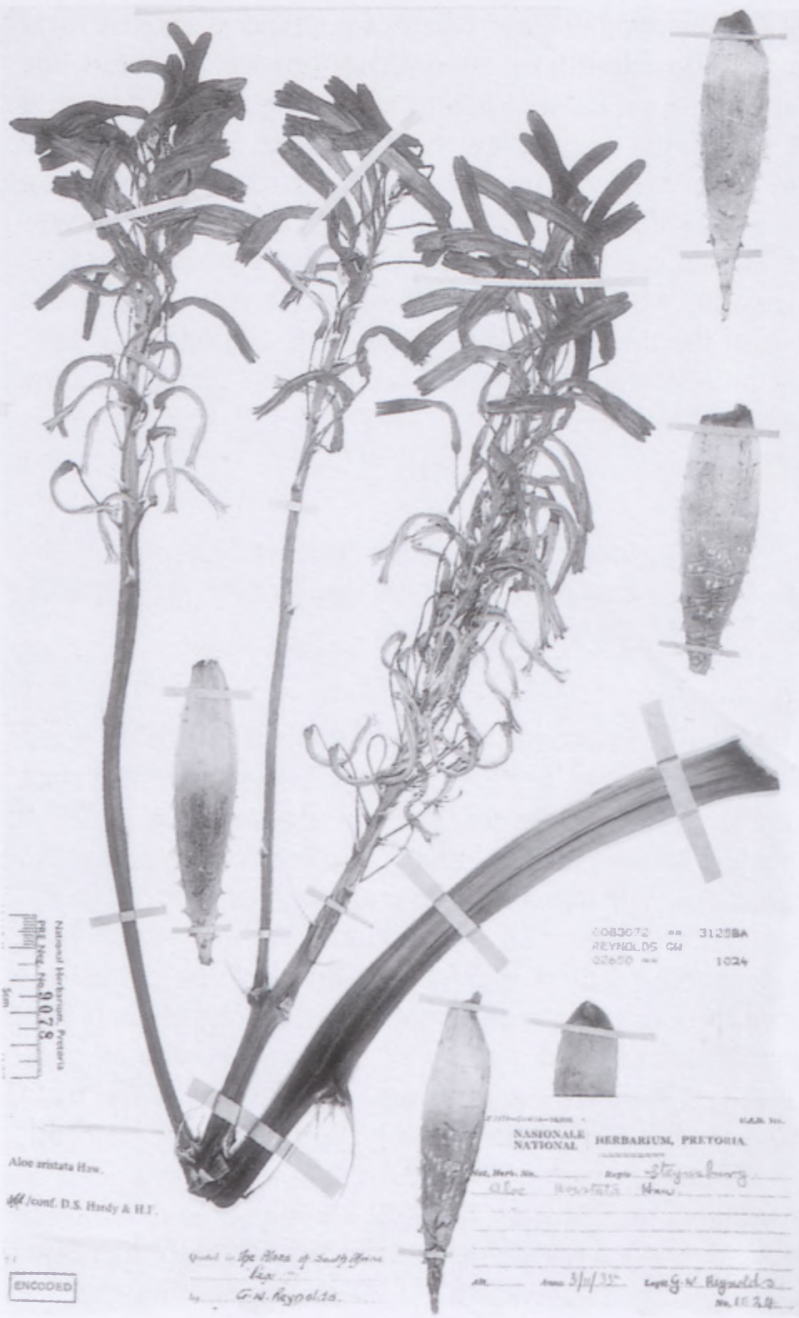

FIGURE 5.-Reynolds 1024, neotype of Aloe aristata.

Schult., the basionym of one of its infraspecific taxa (Figure 7; see below).

Aloe glauca Mill. var. muricata (Schult.) Baker in Journal of the Linnean Society 18: 161 (1880). Neotype: Cape, Piketberg Division, De Hoek, Reynolds 4749 (PRE!; $\mathrm{SAM}$ ! isoneo.)

\section{A. muricata Schult. in Observationes botanicae: 70 (1809).}

No type is cited for A. muricata Schult. and, as in the previous case, neotypification stabilizes current usage of the name.

Aloe saponaria (Aiton) Haw. var. latifolia Haw. in Transactions of the Linnean Society 7: 18 (1804). Neotype (icono.): Ker Gawler in Curtis's Botanical Magazine 34: t. 1346 (1811), here designated.

It is proposed here that the name should be included in the synonymy of Aloe maculata All. Ker Gawler (1811) states 'We have to thank Mr Haworth for the present specimen.' Although Haworth (1804), as usual, gives no clue as to the material he described under var. latifolia, it would be taking caution altogether too far to assume that the plant figured was not at least part of the material of this taxon known to Haworth at the time he coined the name.
Aloe striata Haw. in Transactions of the Linnean Society of London 7: 18 (1804). Neotype: Cape, near Grahamstown, Bottomley s.n. in PRE 27 (PRE!), here designated.

Haworth (1804) mentions, in a cryptic note, a Masson plant we have had no success in tracing. One must therefore assume that this specimen, if it ever existed, has long since disappeared and a neotype may therefore be chosen. This is done here in such a way as to stabilize current usage. The specimen chosen is mounted on two sheets; to obviate future confusion we designate the sheet shown in Figure 8 as 'lectoneotype.'

\section{Aloe thorncroftii Pole Evans}

In the introduction to a paper in which he describes several species of Aloe that are now well known, Pole Evans (1917) states that 'the accompanying descriptions have been made from plants growing in the rockeries in the grounds of the Botanical Laboratories of the Union of South Africa'; that is, the lower western part of the Union Buildings garden in Pretoria. He gives a collector and locality (sometimes more than one) for each species, but never cites a specimen number. This makes locating the intended type specimen somewhat problematical in some cases.

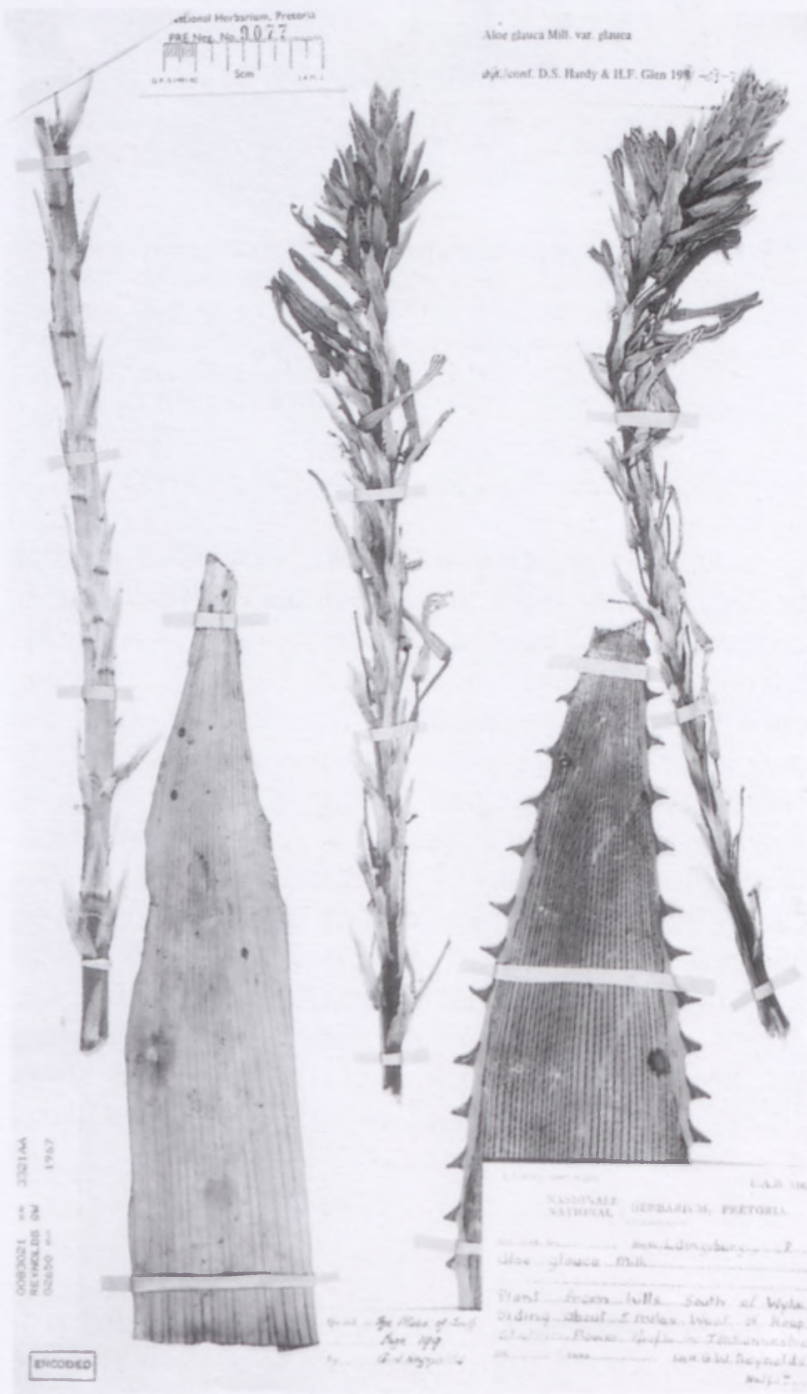

FIGURE 6.-Reynolds 1967, neotype of Aloe glauca. 


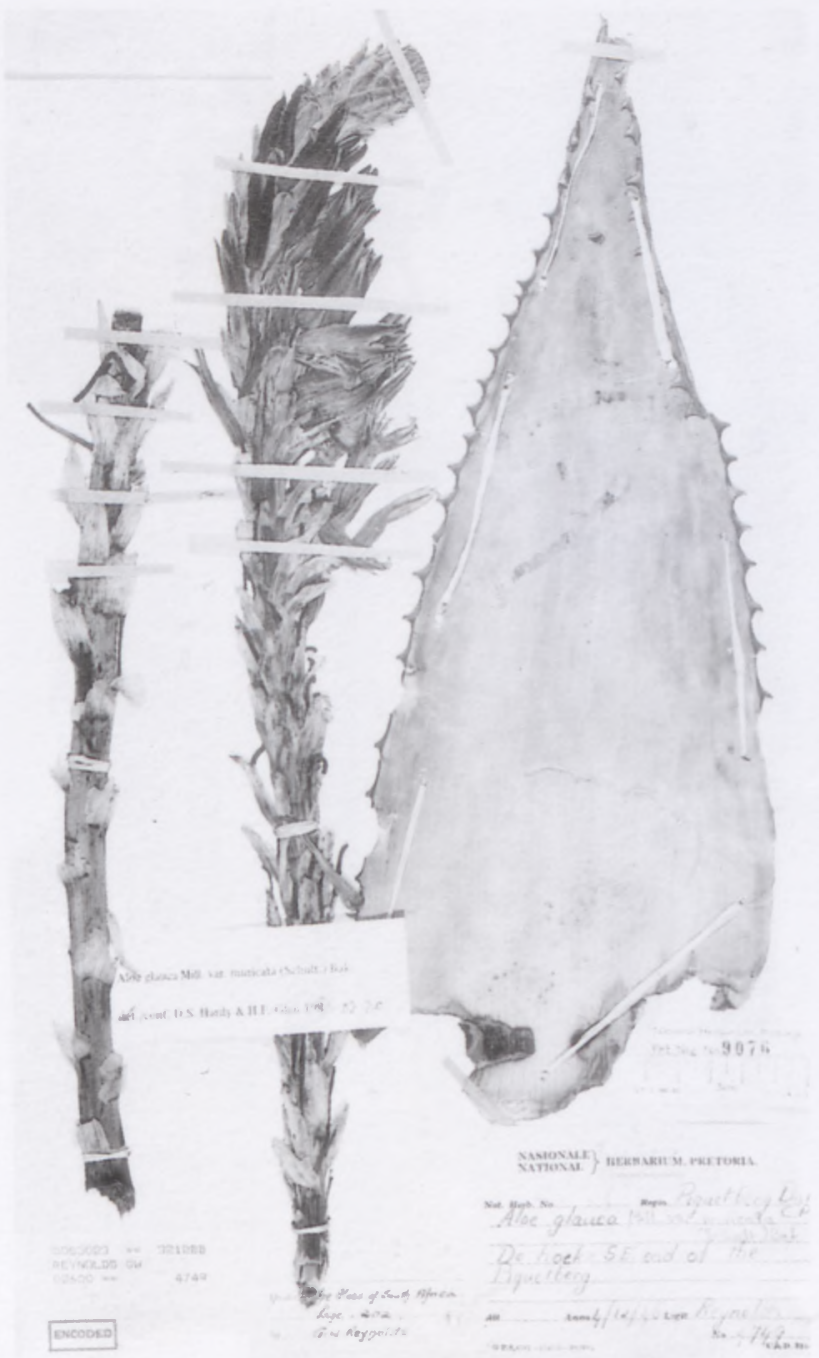

FIGURE 7.-Reynolds 4749, neotype of Aloe muricata.

The protologue of Aloe thorncroftii forms part of Pole Evans's paper, and in this case the only indication of a type is the following paragraph: "All the plants (7) which so far have been flowered in Pretoria have borne an unbranched inflorescence, but Mr George Thorncroft, who first sent me specimens of this Aloe and after whom it has been named, writes me that the inflorescence is branched in the case of some plants.'

One deduces that the type specimen of this species, if one exists, would be marked as having been collected by Thorncroft before 1917, and possibly as having been grown in the Union Buildings grounds. As there are no other specimens from the Union Buildings gardens known in any herbarium except PRE, and as Pole Evans was Chief of the then Division of Botany (later renamed the BRI and finally the NBI), one would search only in PRE for such a specimen. Such a search was undertaken in the course of studies on the southern African species of Aloe by the senior author. Only one specimen fitting these requirements was found (Figure 9). The label is typical of the Pole Evans period, and matches those of many specimens giving their locality only as 'Union Buildings gardens.' The specimen was collected by Thorncroft in 1914 (long enough before the date of publication to allow quite a small plant to grow to flowering size), and is numbered 247 in an unknown series. Neither Pole Evans's collecting register nor the PRE accessions register has a species of Aloe as No. 247, therefore one wonders if the number is from the accessions register of the Vredehuis Garden (predecessor to the Pretoria National Botanical Garden). No register of this date from this garden has survived. It seems that this is the type specimen of Aloe thorncroftii and its correct citation is: TYPE: Transvaal, Barberton, 1914, G. Thorncroft s.n. in PRE 247 (PRE, holo.!).

Aloe pluridens Haw. in The Philosophical Magazine 64: 299 (1824). Neotype: Cape, Ettrick Hills near Carlisle Bridge, Reynolds 1425 (PRE!, here designated).

As usual, Haworth gives no clue as to what material he had available when drawing up his description of this species. Just as in the case of A. aristata, this name was ignored in print for 70 years after the publication of the protologue. In the absence of any contemporary or nearcontemporary illustrations or specimens, a good modern specimen is chosen as neotype (Figure 10).

\section{ACKNOWLEDGEMENTS}

Permission granted by the Director of the Royal Botanic Gardens, Kew, to use copyright material in this article, is gratefully acknowledged.

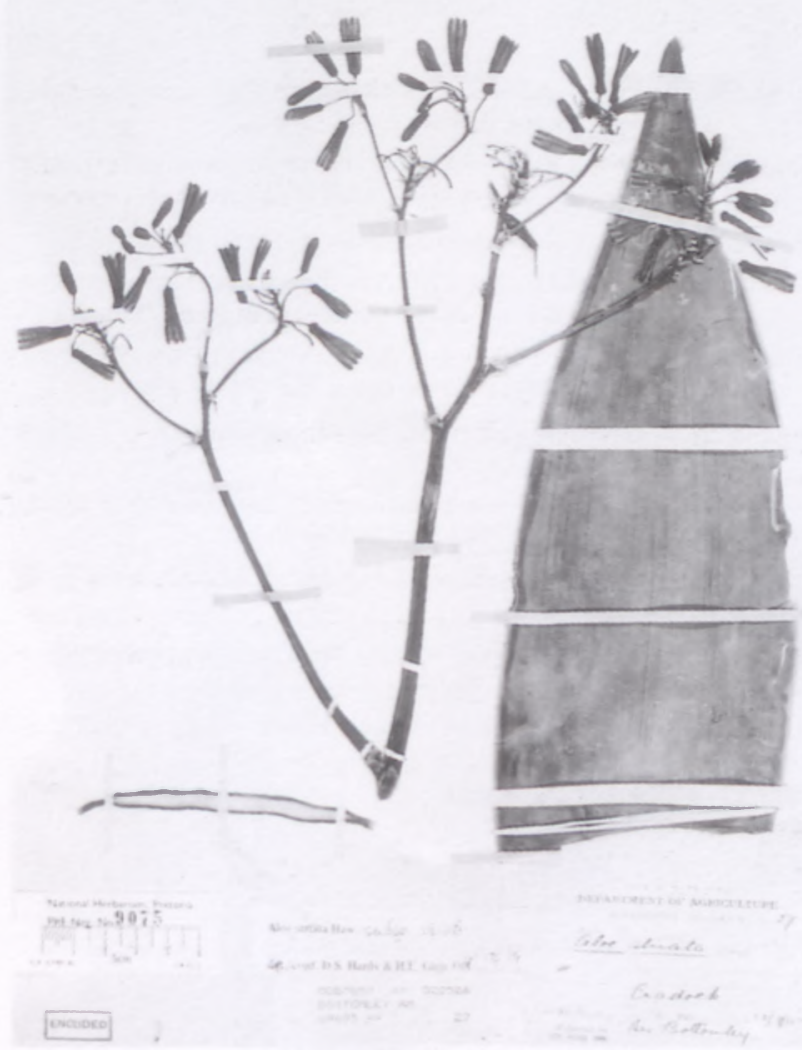

FIGURE 8.-Bottomley s.n. (PRE 27); neotype of Aloe striata. 

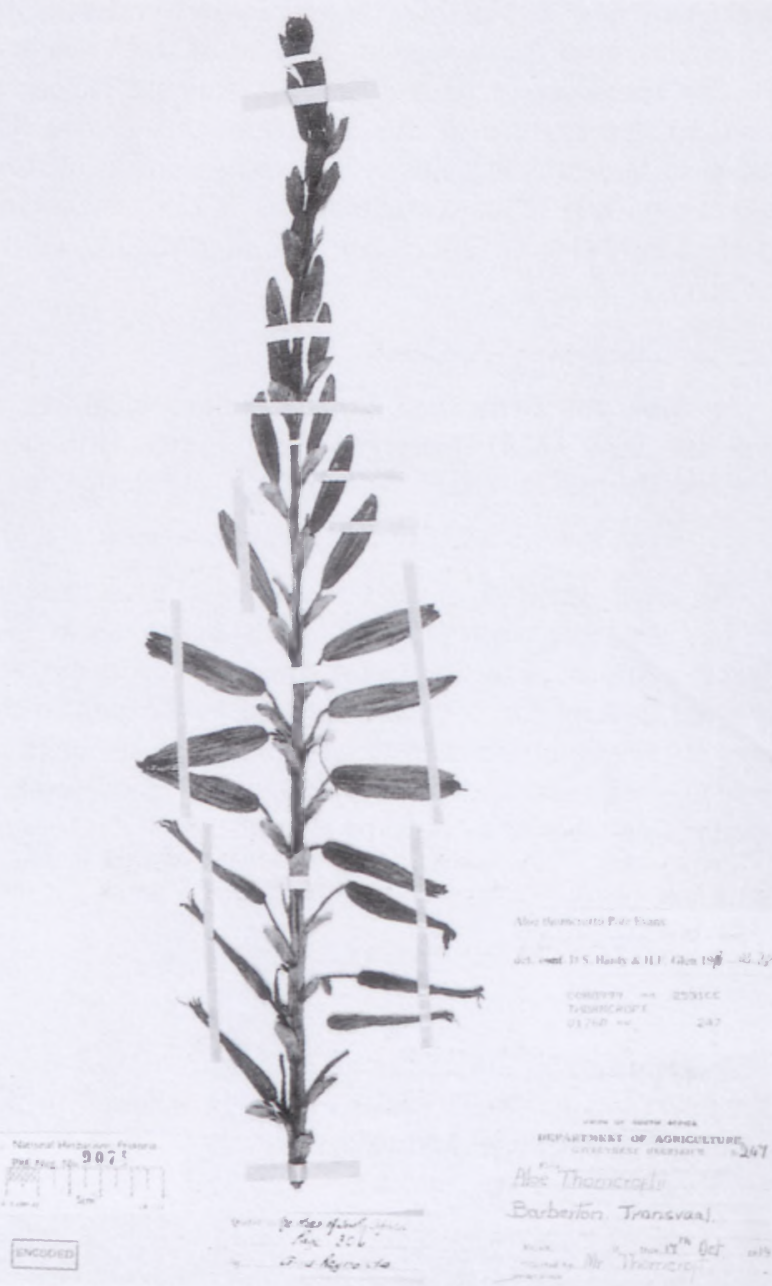

FIGURE 9.-Thorncroft s.n. (PRE 247), holotype specimen of Aloe thorncroftii.

\section{REFERENCES}

BAKER, J.G. 1880. A synopsis of Aloineae and Yuccoideae. Joumal of the Linnean Society, Botany 18: 148-241.

BERGER, A. 1908. Liliaceae-Asphodeloideae-Aloineae. In A. Engler, Das Pflanzenreich 4, 38, III, II (Heft 33). Engelmann, Leipzig.

COMMELIN, C. 1703. Praeludia botanica. Haringh, Leiden.

GLEN, H.F. \& HARDY, D.S. 1991. The type specimen of Aloe soutpansbergensis (Liliaceae/Asphodelaceae). Bothalia 21: 151, 152.

GROENEWALD, B.H. 1936. 'n Nuwe aalwyn van die Wolkberg. Transvaal. Tydskrif vir Wetenskap en Kuns 14: 64-66.

GUNN, M.D. \& CODD, L.E. 1981. Botanical exploration of southern Africa. Balkema, Cape Town.

HAWORTH, A.H. 1804. A new arrangement of the genus Aloe. Transactions of the Linnean Society of London 7: 1-28.

HAWORTH, A.H. 1819. Supplementum plantarum succulentanum. Harding, London.

HAWORTH, A.H. 1824. Decas secunda novarum plantarum succulentarum. Philosophical Magazine 64: 298-302.

HAWORTH, A.H. 1825. Decas quinta novarum plantarum succulentarum. Philosophical Magazine 66: 279-283.

KER GAWLER, J.B. 1805. Aloe humilis var. incurva. Curtis's Botanical Magazine 21: t. 828.

KER GAWLER, J.B. 1811. Aloe saponaria var. Lattfolia. Curtis's Botanical Magazine 34: t. 1436.

MILLER, P. 1768. The Gardeners' Dictionary, edn 8. Rivington, London.

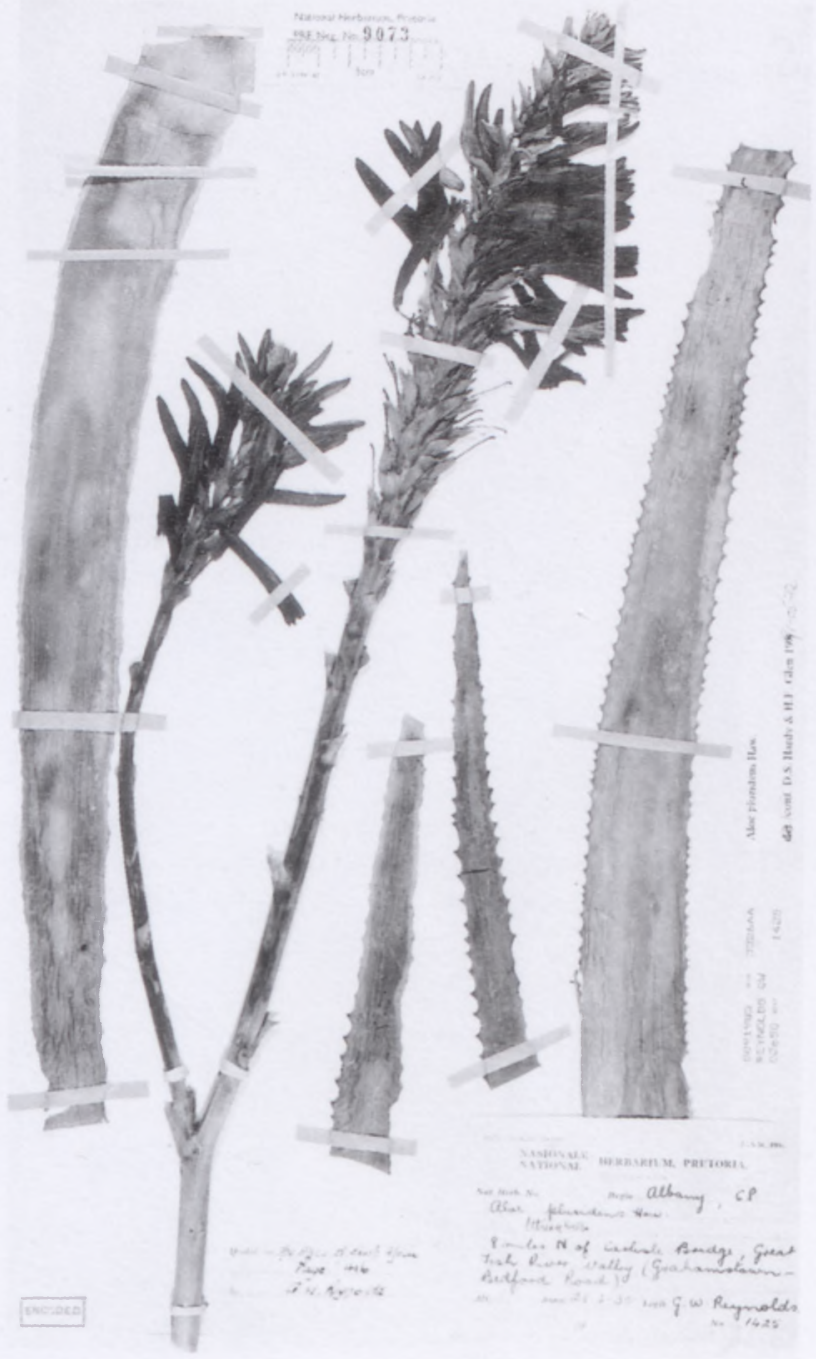

FIGURE 10.-Reynolds 1425, neotype of Aloe pluridens.

POLE EVANS, I.B. 1917. Descriptions of some new aloes from the Transvaal, part II. Transactions of the Royal Society of South Africa 5: 703-712.

PRINSLOO, H.D.A. 1972. A rare aloe. Veld \& Flora 2: 16, 17.

REGEL, E.A. VON, 1879. B. Aloë Schmidtiana Rgl. Liliaceae. Gartenflora 97: t. 970.

REYNOLDS, G.W. 1946. Aloe thompsonii. The Flowering Plants of Africa 25: t.980.

REYNOLDS, G.W. 1950. Aloes of South Africa. Aloes of South Africa Book Fund, Johannesburg.

SALM-DYCK, J.M.F.A.H.I. 1837. Monographia generum Aloës et Mesembryanthemi, Aloe longiaristata. Fasc. 2, fig. 21 (Sect. 15, fig. 7). Düsseldorf.

SCHULTES, J.A. 1809. Observationes botanicae. Innsbruck.

SCHULTES, J.A. \& SCHULTES, J.H. 1829. Classis VI, Hexandria Monogynia Genera, 1417. Aloe. In J.J. Roemer \& J.A. Schultes, Systema vegetabilium 7,1: 684. Sumptibus J.G. Cottae, Stuttgartiae.

SIMS, J. 1821. Aloe microcantha. Curtis's Botanical Magazine 48: t. 2272.

SMITH, G.F. 1990a. Neotypification of Aloe bowiea (Asphodelaceae: Alooideae). South African Journal of Botany 56: 415-418.

SMITH, G.F. 1990b. Neotypification of Bowiea myriacantha, basionym of Aloe myriacantha (Asphodelaceae: Alooideae). Botanical Bulletin of Academia Sinica (new series) 31: 315-320.

SMITH, G.F. 1993. Notes on the taxonomic and conservation status of Aloe microcantha (Asphodelaceae: Alooideae). Haseltonia I: $55-60$.

WIJNANDS, D.O. 1983. The Botany of the Commelins, Balkema, Rotterdam. 